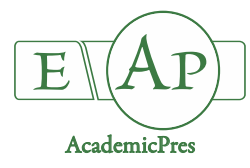

\title{
Ecology, Cultivation and Utilization of the Aromatic Greek Oregano (Origanum vulgare L.): A Review
}

\author{
Elpiniki SKOUFOGIANNI ${ }^{1 *}$, Alexandra D. SOLOMOU², \\ Nicholaos G. DANALATOS ${ }^{1}$ \\ ${ }^{1}$ University of Thessaly, Laboratory of Agronomy and Applied Crop Physiology, Department of Agriculture, Crop Production and Rural \\ Environment, Fytokou str., 38446, N. Ionia, Magnisia, Volos, Greece; eskoufog@uth.gr(*correspondingauthor); danal@uth.gr \\ ${ }^{2}$ Institute of Mediterranean Forest Ecosystems, Hellenic Agricultural Organization “Demeter”, N. Chlorou 1, 11528, Greece; solomou@fria.gr
}

\begin{abstract}
Medicinal and aromatic plants represent a stable part of the natural biodiversity legacy of many countries in the world. The present review focuses on oregano (Origanum vulgare L.; family Lamiaceae), an endemic herb in Greece that constitutes one of the best known aromatic and medicinal plants originating in the Mediterranean region. In particular, oregano is an evergreen, rich in natural compounds perennial plant that received increased attention in the last years for a wide range of uses. Oregano dry leaves and inflorescences in mixture are used as human and animal food that is extremely rich in antioxidative properties. Additionally, its essential oil is rich in carvacrol, thymol, c-terpinene and p-cymene, and is used for a number of medicinal purposes, e.g. for inhibiting microbial and fungal toxin production as well as for the well-known anti-inflammatory, analgesic, antiarthritic, antiallergic, anticarcinogenic, antidiabetic, cardioprotective, gastroprotective, hepatoprotective, and neuroprotective properties. Due to its perfect quality and high essential oil concentration, Greek oregano (O. vulgare ssp. hirtum) is regarded among the best in the world gaining in popularity in the global markets for food industry applications. Consequently, oregano might be considered as an important low-input, environmental friendly commodity for extensive cultivation in Greece. The present review summarizes on the origin, the morphology, the ecology and the utilization of this plant. Despite the extensive literature available on the use of oregano biomass and essential oil, only few reports exist concerning the cultivation of this plant. Therefore, the present review is additionally focused on the cultivation practices and the importance of cultivation and utilization of Origanum vulgare L. in Greece and generally in the Mediterranean region in the near future, as it constitutes a plant species with high medical, economic and environmental value.
\end{abstract}

Keywords: cultivation practices; Greek species; multipurpose herb; oregano oil

\section{Introduction}

The Mediterranean Basin is considered as a 'Global biodiversity hotspot' and the largest of the world's five Mediterranean type climatic regions (Beltran et al., 2014; Solomou et al., 2017). The geographical position of Greece combined with its richness in different landscapes and edapho-climatic environments and their multiple interactions with the biotic factors have designated it as a region of great importance regarding biodiversity and plant endemism, particularly favouring the adaptation of aromatic and medicinal plant species that offer therapeutic, economic and environmental benefits (e.g. Origanum sp., Sideritis sp., Salvia sp., Crocus sp., Hypericum perforatum, etc.) (Katsiotis and Chatzopoulou, 2010; Solomou et al., 2016).
Oregano constitutes one of the most cultivated aromatic plants worldwide. Due to its perfect quality and high essential oil concentration, Greek oregano is regarded among the best in the world gaining in popularity in the European markets for food industry applications (Goliaris and Skroumpis, 1992). Depending on the origin, the essential oil concentration ranges from 1.1 to $8.2 \%$ that is about 10 times greater compared to other oregano species (Kokkini and Vokou, 1989; Baser et al., 1993).

Greek oregano grows particularly on mountains and hills, but the plant started to be cultivated in many Greek lowlands, as for example in the plains of Karditsa, Trikala, Magnisia, Rodopi, Kilkis and Thessaloniki. Greek oregano has also been detected in the Balkan Peninsula, e.g. in Turkey, Cyprus, Italy (Sicily) (Siedemann, 2004), particularly at elevations between 0 and $1500 \mathrm{~m}$ ASL (Kokkini et al., 2004). 
546

Goliaris et al. (2002) created four new oregano clones in Greece from indigenous plant material (varieties) grown in North and Central Greece (see Fig. 1). The criteria on which the selection was based comprised plant shape, bloom time, yield, essential oil content and dry plant color.

Despite the wide research on the essential oil concentration and components as well as the secondary metabolites of the Origanum vulgare L. (Dhifi et al., 2016), only few reports exist concerning the cultivation practices of this plant. Therefore, the aim of the present review is to present comprehensive information about the importance of cultivation and utilization of Origanum vulgare L. in Greece and generally in the Mediterranean area, as it constitutes a plant species with high medical, environmental and economic value.

\section{Methodology}

A literature search was conducted using Scopus, Web of Science and Google Scholar, with the aim to review and consolidate the existing research on the cultivation and utilization of Origanum vulgare L. in Greece. A systematic methodology was applied so as to ensure a rigorous and repeatable method of cultivation and utilization of Origanum vulgare L. The methodology consisted of the following phases: (a) the generation of keywords and (b) a systematic search (Harrison et al., 2014).

\section{Oregano types and plant morphology}

Oregano belongs to the Lamiaceae family of the order Lamiales (Makri, 2002). The genus Origanum includes more than 70 species, 49 taxa (species and subspecies) and natural hybrids found in almost all Mediterranean countries, but also in the temperate zones of Asia and America (Kintzios, 2002). The most important types of oregano are: a) Greek oregano (Origanum vulgare ssp. hirtum), b) Spanish oregano (Coridothymus capitatus L.), c) Turkish oregano (Origanum onites L.), d) Mexican oregano (Lippia graveolens HBK (Lawrence, 1984), e) Origanum vulgare L. ssp. vulgare, f) Origanum vulgare ssp. viridulum, and g) Origanum vulgaris L. (Kokkini and Vokou, 1989).

Generally, oregano plants grow $20-90 \mathrm{~cm}$ in height and are characterized by egg-shaped leaves $10-40 \mathrm{~mm}$ long and 5-25 mm wide, with the wider end at the base, and with smooth or very shallowly toothed edges and leaf tips varying from acute to round-shaped. The inflorescence is manyflowered, with flowers grouped into short dense lateral or terminal spikes. The corolla (ring of united petals) is white to purplish, 4-8 $\mathrm{mm}$ long, and has two lips. The calyx (ring of united sepals) is five-toothed. Each flower has four stamens (male parts). Each fruit has four small nutlets (single-seeded units).

A number of studies have shown that variation in morphological and chemical features may occur within a single oregano species. It has been found that the pattern of variation of a single species follows its geographical distribution or it depends on the season of plant collecting. The range of three subspecies found in Greece is associated with the climatic conditions prevailing in each area. $O$. vulgare subsp. hirtum (syn. O. hirtum Link, O. heracleoticum auct. non L.), is mainly found on the islands and southern mainland (Fig. 1), whereas toward the north it is mostly confined to the lowland coastal areas. Its distribution range in Greece is limited by the presence of the continental type of climate in the northern and central part of the mainland (Kokkini et al., 1991). From the morphological point of view, subsp. hirtum can be distinguished by its small green bracts and white flowers. Toward the northern parts of Greece, where a continental Mediterranean climate occurs, subsp. Oregano hirtum is replaced either by subsp. viridulum [syns. O. heracleoticum L., O. viride (Boiss.) Halácsy] characterized by large green bracts or by subsp. vulgare. The latter is easily distinguished by the large purple bracts and pinkish to purple flowers. The number and the size of the sessile glands in leaves, bracts and calyces are remarkably reduced in samples from the southern to the northern part of the country. These glands which appear as small bladders are the peltate glandular hairs described by Bosabalidis and Tsekos (1984), Werker $e$ al. (1985). Since they contain the bulk of the secreted essential oil, the reduced number of sessile glands is connected with low essential oil content (Bosabalidis and Kokkini, 1996). The subsp. hirtum plants, though very variable in leaf and bract sessile gland number, but always characterized by densely glandular calyces, are in any case rich in essential oil (1.8-8.2 ml/100 g dry weight). On the other hand, plants belonging to the other two subspecies, having fewer and smaller (inconspicuous) sessile glands, contain a much lower amount of essential oil (traces up to $0.8 \%$ ) (Kokkini and Vokou, 1989; Kokkini et al., 1991, 1994).

\section{Crop ecology and cultivation practices}

The wild oregano species can grow at different altitudes from coastal to mountainous areas in undulating to rolling terrains (Goliaris, 1997b) on various soils with different fertility status, able to withstand rather low temperatures, and finally produce high yields of good quality. However, $O$. vulgare ssp. hirtum may be extensively cultivated and play a very important role in the Greek economy.

\section{Climate and soils}

A number of relevant studies including the effects of temperature and day length have been conducted by various authors (Cohen et al., 1980; Putievsky, 1983; Dudai, 1988; Putievsky et al., 1988; Dudai et al., 1989; Dudai et al., 1994). According to these studies, air temperature for optimum oregano growth and development range from 18 ${ }^{\circ} \mathrm{C}$ to $22{ }^{\circ} \mathrm{C}$, whereas the root system of well-developed plants (older than one year) may withstand air temperatures from $-25{ }^{\circ} \mathrm{C}$ to $42{ }^{\circ} \mathrm{C}$ (Koutsos, 2006). However, temperatures below $4{ }^{\circ} \mathrm{C}$ or above $33{ }^{\circ} \mathrm{C}$ may limit plant growth. The plant grows in a wide variety of soils and climates from seaside to mountainous areas on the islands and mainland of Greece $(1500 \mathrm{~m})$, in rich as well as on poor calcareous soils. An excellent soil $\mathrm{pH}$ value is around 6.8, but oregano may be found on calcareous soils with much higher $\mathrm{pH}$ values. Generally, a long light period is needed (more than 12 hours) for a high content of essential oil and carvacrol. 

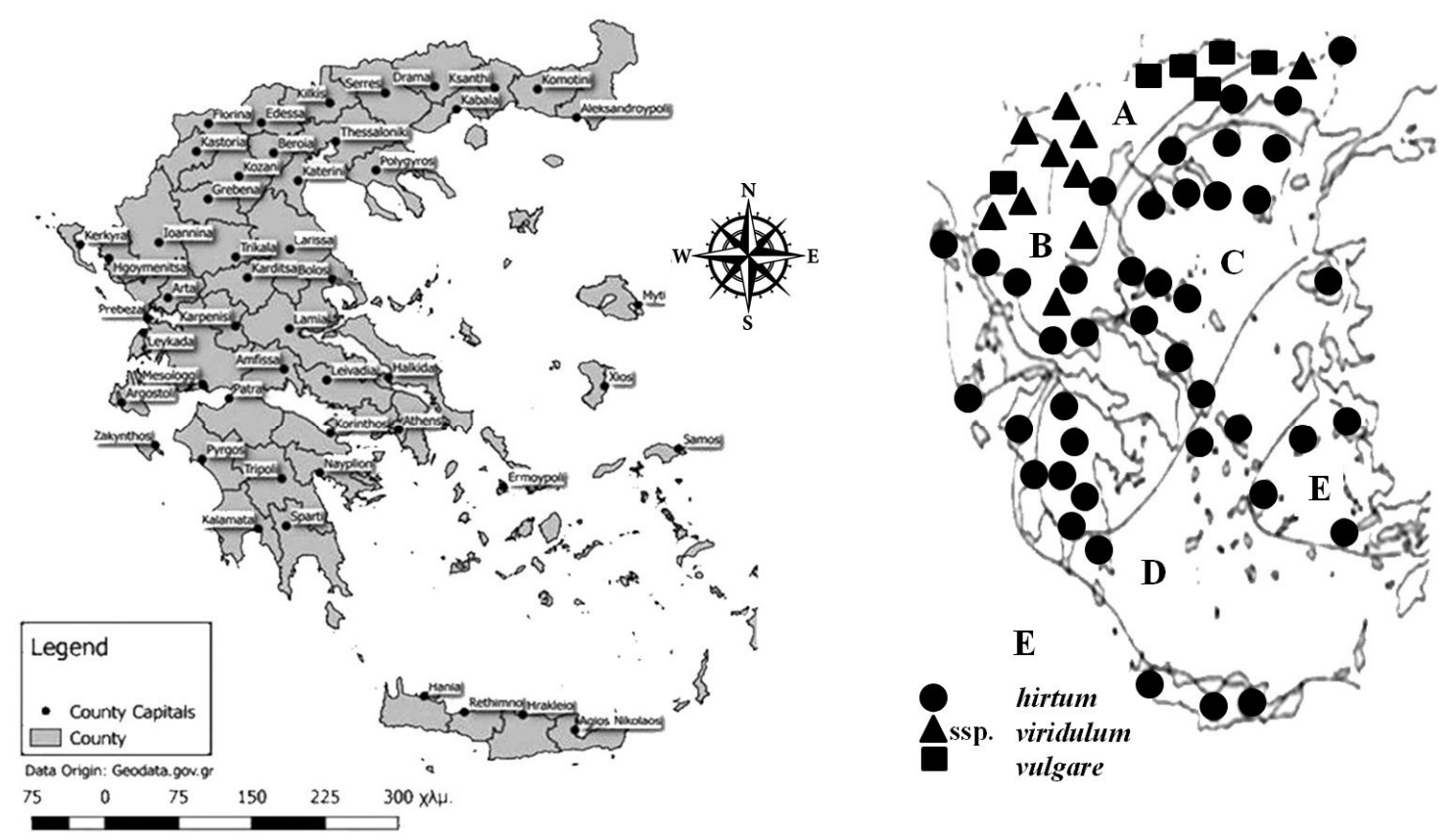

Fig. 1. Origanum sp. distribution in Greece (Kokkini et al., 1994)

Moreover, as many other species, oregano plants grown under different temperature or light regimes flower earlier as temperature and light increase.

As the day becomes longer - due to natural or artificial light - essential oil content increased and its composition changed. On the basis of these results it is apparent that the origin of this variation is linked to changes in the photosynthesis of the plant. There is a relationship between number of leaves per plant and plant parts and the essential oil content and composition, as well as between the number and type of glandular hairs (Werker et al., 1985a, 1985b; Dudai et al., 1988c).

\section{Field preparation and planting}

A deep winter ploughing is advisable followed by a light tillage just prior to planting. Before planting, a final plowing is suggested to cover the fertilizer and for the destruction of weeds, and to facilitate the transplantation, particularly when this is done mechanically.

Greek oregano is primarily collected from wild populations. The $O$. ssp. hirtum has great variability in the essential oil content and carvacrol percentage, so clones of high yield and quality were developed for introduction into cultivation.

As oregano seeds are very small $(0.20-0.25 \mathrm{~g}$ per 1000 seeds), direct sowing in the field is not recommended for commercial cultivation because of the generally low germination rates, the heterogeneity of the young plants and the considerable delay in yield production (Putievsky et al., 1982). Instead, seedlings are prepared using rooted or unrooted stem cuttings (Kuris et al., 1981). The seedlings are transplanted in the field in the period March-April. Plant density greatly affects plant yield and number of branches (Marzi, 1996). Field experimental results have shown that planting in rows with about $8-10$ plants $/ \mathrm{m}^{2}$ might be optimum, with distances $60-80 \mathrm{~cm}$ between the rows and $30-40 \mathrm{~cm}$ on the row (Katsiotis and Chatzopoulou, 2010) for proper hoeing and mechanical weeding.

\section{Fertilization - Irrigation}

High dry matter yields are associated with increased $\mathrm{N}$ P-K dressings. According to Dordas et al. (2009) nitrogen is an important element for increasing dry matter yields without affecting the essential oil content significantly. Oregano plants remove from the field $25-86 \mathrm{~kg} \mathrm{~N} \mathrm{ha}^{-1}$ (Dordas, 2012). A basic application with a mixed-type fertilizer (e.g. 13-10-10) by the end of winter to early spring is satisfactory. After the first cutting, an additional fertilizer implementation may be needed. Apart from the macroelements, sodium and secondarily copper might be also required. However, high levels of copper in the soil may be blamed for small, clorotic oregano leaves, with many stomata and few chloroplasts (Panou-Filotheou et al., 2001).

As oregano is rather tolerant to drought (Katsiotis and Chatzopoulou, 2010; Marques et al., 2012), it can be cultivated as rainfed crop. However, during particularly dry periods, one or two irrigation applications with about 40-50 $\mathrm{mm}$ per application may substantially increase yield without negatively affecting yield quality.

\section{Weeds - Pests and diseases control}

Weed control in a perennial crop such as oregano is necessary to keep the crop clean throughout the growing period. Especially in the year of establishment, weed control is very important especially by the end of winter-onset of spring.

As many winter or summer species infest oregano fields, tilling is therefore frequent, taking place at least two or three times a year (e.g. in autumn, spring and summer) (Marzi, 1996). 
548

\section{Harvest}

The exact time of harvesting is determined on the yield quality basis, e.g. essential oil content upon flowering (usually mid-June to late August). Harvesting is normally carried out mechanically, whereas post-harvest processing is occasionally manual. The plants are cut $5-8 \mathrm{~cm}$ above ground. If the crop is irrigated, a second harvest may be possible; in this case, irrigation is needed immediately after the first harvest. Oregano is harvested at full blooming for essential oil production or at the beginning of flowering for herb production. Significant differences in yield and oil content have not been observed during the flowering period. Oil content in leaves is very low in the autumn (October) harvest. Highest yields are obtained in the second year, during the two cuts made in June-July and in October. Dry oregano yields may reach 1.5-3.0 $\mathrm{t} \mathrm{ha}^{-1}$, whereas the total duration of Greek oregano cultivation may exceed 1011 years. A rough estimate of an average crop production (subject to further verification) indicates a value of $20 \mathrm{t} \mathrm{ha}^{-1}$ in a 4-year cultivated field. A full crop performance may be attainable after the first year of establishment. The harvest index is about $50-55 \%$ in the first harvest owing to the high incidence of stems and ca. 60-70\% in the second mowing usually done in October. Finally, if oregano is intended for the market as fresh or frozen product, the plants can be harvested every 5-6 weeks. In this case, the upper plant parts are cut before flowering can be set.

\section{Processing}

The drying method plays major role for producing a high-quality product. During the drying process, drying temperatures are $30-40{ }^{\circ} \mathrm{C}$ should not be exceeded as they negatively affect the oil content (Marzi, 1996). The final product consists of a mixture of leaves and flowers, which account for about $40-60 \%$ of the aerial part of the dried plants. The relative volume by weight (specific gravity) of the fresh air portion is $80-120 \mathrm{~kg} \mathrm{~m}^{-1}$ (Katsiotis and Chatzopoulou, 2010). As direct exposure to sun can be rather dangerous, drying should take place in shade by spreading the harvested material in thin coats and applying ventilation of dry air. Another method is drying by heating. It is used on an industrial level where moisture is dropped by discharging hot air. An alternative form of artificial drying that is well used in the food industry for effective drying aromatic and medicinal plants is freeze drying known as lyophilization. The product is cooled and then dried by sublimation of ice in a vacuum. The advantage of this method is the stability of the plant material properties, but its substantial cost comprises a serious drawback.

\section{Essential elements composition and oregano utilization \\ Elements composition}

The essential oil content, as well as the ratio of carvacrol to thymol to the total oil amount is rather variable in the different Greek oregano populations. The very high values of essential oil yield ( $>7 \mathrm{ml} / 100 \mathrm{~g} \mathrm{dm}$ ) have been recorded on Crete and Amorgos islands, as well as in Gythion and Athos Peninsula. In some cases, the essential oil consists of a high carvacrol quantity, as in the South Peloponnese (more than $90 \%$ of the total oil), or in other cases thymol comprises the predominant phenol (Corfu Island). In these cases, carvacrol, i.e. the compound characterizing the oregano plant, is a minor constituent. The dominance of thymol suggests that these should belong to the group of plants used as thyme (Fig. 2, Table 1).

The essential oil content is much lower in autumn plants, ranging from 1.0 to $3.1 \%(\mathrm{ml} / 100 \mathrm{~g} \mathrm{dm})$, compared with those collected from the same areas in summer (4.8$8.2 \%)$. The most impressive difference is the increased amount of p-cymene in autumn: its amount ranges from 17.3 to $26.9 \%$ of the total oil in plants from South Peloponnese and Crete (instead of $4.0-9.5 \%$ found in the summer plants) to $37.1-51.3 \%$ of the oil in plants from Athos peninsula (instead of $12.0-12.2 \%$ in the summer) (Kokkini et al., 1996).

These results suggest that the essential oils of $O$. vulgare subsp. hirtum are characterized by stability, irrespective of harvesting time, with regard to (1) the high concentration of the sum of the four components involved in the phenolic biosynthetic pathway, and (2) the predominant phenol type. It should be noted that the two monoterpene hydrocarbons are very common constituents of all 'oregano' or 'thyme' type essential oils (Fig. 3) (Lawrence, 1984; Ravid and Putievsky, 1986; Kokkini, 1994).

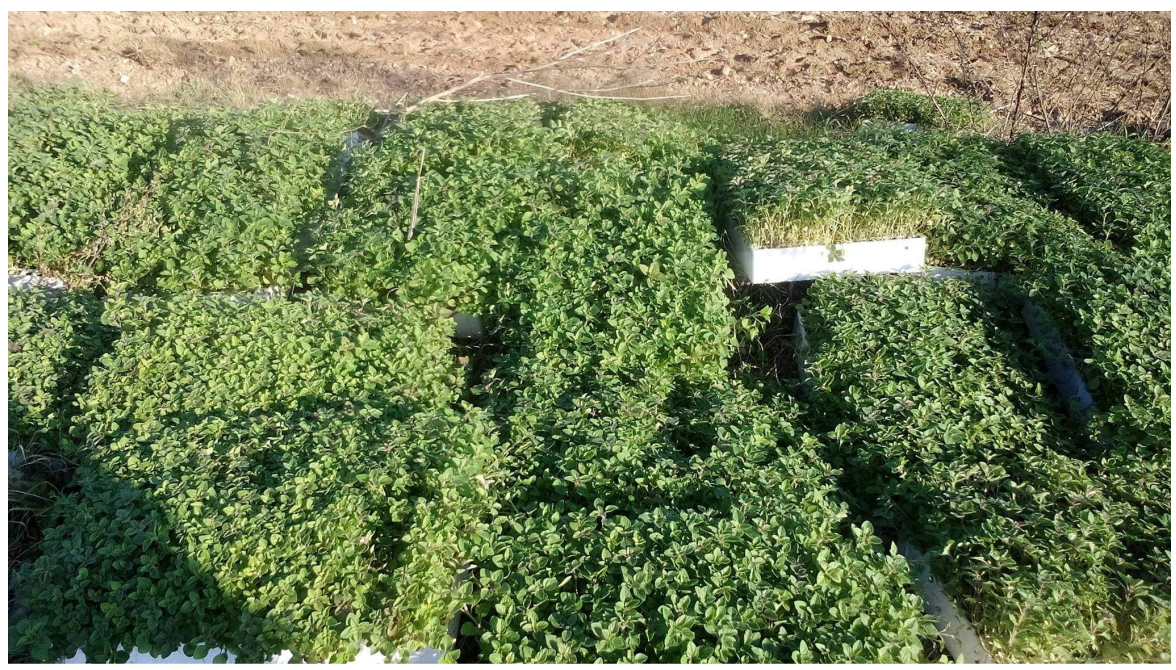

Fig. 2. Origanum vulgare subsp. hirtum (from an experimental field at University of Thessaly) 


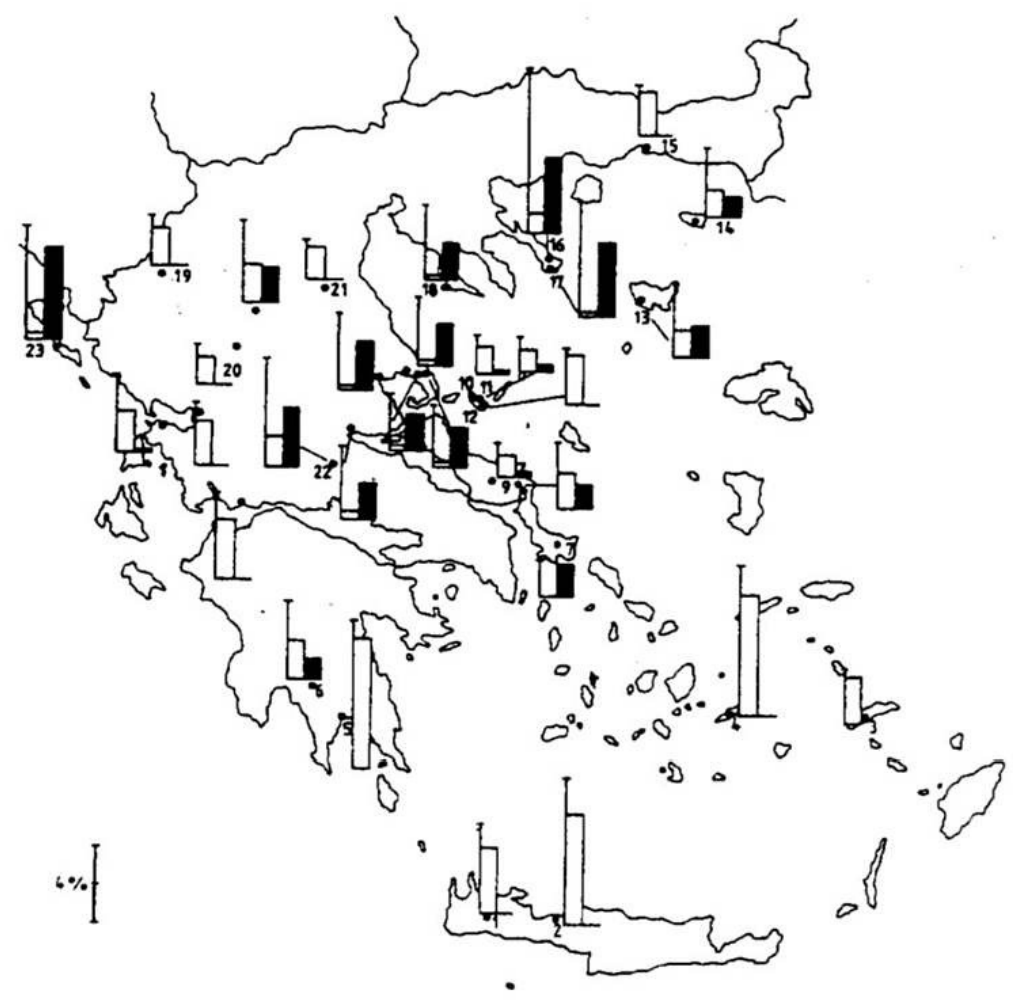

Fig. 3. Essential oil yield, carvacrol (white bars) and thymol (black bars) contents (as percentages of the total oil) of Origanum vulgare subsp. hirtum, in different Greek localities (after Vokou et al., 1993)

Table 1. Essential oil composition of 4 new oregano clones in Greece (Goliaris et al., 2002)

\begin{tabular}{|c|c|c|c|c|}
\hline Components & Olympos & Vermio & Pilio & Athos \\
\hline \multicolumn{5}{|c|}{$\%$ of total oil } \\
\hline a-Thujene & 0.07 & 0.81 & 0.12 & 0.52 \\
\hline a-Pinene & 0.07 & 0.65 & 0.21 & 0.48 \\
\hline Camphene & 0.06 & 0.15 & 0.05 & 0.09 \\
\hline Sabinene & 0.50 & 0.80 & 1.12 & 0.66 \\
\hline Mycrene & 0.13 & 1.70 & 0.40 & 1.09 \\
\hline a-Phellandrene & - & 0.17 & - & 0.02 \\
\hline a-Terpinene & - & 0.73 & 0.22 & 0.40 \\
\hline p-Cymene & 0.74 & 4.25 & 4.05 & 8.10 \\
\hline Terpinolene & 0.08 & 0.21 & 0.10 & 0.14 \\
\hline Limonene & - & 0.17 & 0.08 & 0.16 \\
\hline$\Gamma$-Terpinene & 0.55 & 2.43 & 0.32 & 0.63 \\
\hline Trans-sabinen-hydrate & 0.02 & 0.51 & 0.31 & 0.46 \\
\hline Terpinen-4-ol & 0.42 & 0.42 & 0.49 & 0.43 \\
\hline a-Terpineol & 0.31 & 0.26 & 0.12 & 0.19 \\
\hline Thymol & 0.32 & 0.28 & 0.04 & 0.55 \\
\hline Carvacrol & 92.90 & 82.68 & 86.97 & 79.45 \\
\hline a-Cubenene & 0.08 & 0.08 & 0.09 & 0.06 \\
\hline b-Caryophyllene & 0.30 & 0.70 & 1.58 & 1.29 \\
\hline Trans b-Farnesene & 0.11 & 0.12 & 0.09 & 0.14 \\
\hline a-Humulene & 0.06 & 0.08 & 0.19 & 0.09 \\
\hline Muurolene & 0.17 & 0.16 & 0.04 & 0.08 \\
\hline$\gamma$-Cadinene & 0.24 & 0.08 & 0.60 & 0.70 \\
\hline
\end{tabular}


550

\section{Oregano utilization}

Aromatic plants produce organic compounds that may be involved in the defense of plants against phytopathogenic insects, bacteria, fungi, and viruses. Most essential oils of the family Lamiaceae consist of monoterpenes and sesquiterpenes. Their activity is attributed to the content of carvacrol and thymol which are accompanied by p-cymene and cterpinene that are the major constituents in oregano (Vokou et al., 1993).

Oregano is an important aromatic herb for its flavor and use as food (mixture of dry leaves and inflorescences) but also for its important medicinal uses. The essential oil of Origanum vulgare ssp. hirtum shows a high content of carvacrol, thymol, c-terpinene, and p-cymene, representing $73.7 \%, 92.8 \%$, and $87.78 \%$ of the total oil, respectively (Sivropoulou et al., 1996; Lewinsohn et al., 2000; Bouchra et al., 2003; Baydar et al., 2004; Bozin et al., 2006).

Its activities include antioxidative properties in food (e.g. lard, sunflower oil) and in vivo and the inhibition of foodborne and human antibiotic-susceptible and antibioticresistant pathogenic bacteria, viruses, pathogenic fungi, parasites, insects in vitro and in human foods (e.g. apple juice, eggs, leafy greens, meat and poultry products, milk, oysters) and food animal feeds and wastes (Kirimer et al., 1995; Adam et al., 1998; Ozkan et al., 2003; Chami et al., 2005; Tajkarimi et al., 2010). Also, it covered inhibitions of microbial and fungal toxin production and the antiinflammatory, analgesic, antiarthritic, antiallergic, anticarcinogenic (Conforti et al., 2008), antidiabetic, cardioprotective, gastroprotective, hepatoprotective, and neuroprotective properties of carvacrol as well as metabolic, synergistic, and mechanistic aspects (Bozin et al., 2006; Friedman, 2014).

Oregano is used as a seasoning food in cooking, and less as a beverage, which is referred to as excellent against coughing. For example, the essential oil of $O$. hirtum rich in carvacrol has been used as medicinal (Baricevic and Bartol, 2002), whereas the essential oil of $O$. dubium is used as antirheumatic (Arnold et al., 1993). Oregano has 12 times more an antioxidant action than orange, 30 times more than potato and 42 more than apple.

The therapeutic value of oregano was known already from ancient times. The ancient Greeks were drinking oregano tea in colic and also for external uses. The essential oil of oregano inhibits completely the mycelial growth of Aspergillus niger and $A$. flaous at $400 \mathrm{mg} / \mathrm{ml}$, while $A$. ochraceus is inhibited at $600 \mathrm{mg} / \mathrm{ml}$. Fungal spore germination is inhibited by $600 \mathrm{mg} / \mathrm{ml}$ of origanum oil and (with the exception of $A$. ochraceus) with $700 \mathrm{mg} / \mathrm{ml}$ of thyme oil (Paster et al., 1990). Under aerobic conditions, the essential oil of oregano $(250 \mathrm{mg} / \mathrm{ml})$ inhibited to some extent the growth of Staphylococcus aureus and Salmonella typhimurium. Pseudomonas aeruginosa was not affected by oregano oil at concentrations up to $500 \mathrm{mg} / \mathrm{ml}$. The origanum oil is very effective against Campylohacter jejuni and Clostridiurn sporogenes. The essential oil of $O$. vulgare ssp. hirtum is extremely bactericidal at $1 / 4000$ dilution and even at dilutions as high as 1/50000 caused a considerable decrease in bacterial growth rates. The same essential oil also exhibits high levels of cytotoxicity against four permanent animal cell lines including two derived from human cancers (Paster et al., 1990; Sivropoulou et al., 1996). Carvacrol causes a total obstructing in the development of colonies of fungus Penicillium digitatum, Fusarium solani var. coeruleum and Botrytis cynerea (Daferera et al., 2000; Kulisic, 2004; Chami et al., 2005).

The oil of $O$. vulgare shows a strong antibacterial action against Gram-negative bacteria (Esherichia coli, Salmonella typhimurium, Proteus, Yersinia enterocolitica, Serratia marcenscens, Pseudomonas flourescens and Pseudomonas putida), as well as positive, Gram-negative bacteria (Micrococcus sp., Sarcina flava, Staphylococcus aureus, Bacillus licheniormis, Bacillus thuringiensis and Listeria innocua) compared with the essential oils of other plants while their biosynthetic precursors c-terpinene and pcymene were inactive (Pellequer et al., 1980; Gergis et al., 1990; Remmal et al., 1993; Sivropoulou et al., 1996; Marino et al., 2001). The essential oils of O. vulgare (onites and hirtum) show strong antibacterial action to the Stenotrophomonas maltophilia (Sarac et al., 2009). Also, the rich quantity in carvacrol of Origanum vulgare show the same strong activity against the bacteria $E$. coli, S. aureus, Bacillus megaterium and Salomonella badar (Remmal et al., 1993). The results of the study encourage the examination of the effectiveness of the essential oil of oregano against other pathogens, which are non-discriminatory and those that cause malignant diseases (Manohar et al., 2001).

\section{Conclusions}

Aromatic and medicinal plants have gained much popularity in European and global markets in the last decade. The yields of such plants and particularly of Origanum vulgare obtainable in Greece are of high quantity and best quality. Thus, the introduction of oregano in crop rotation systems in Greece should be seriously considered for the near future. It is believed that cultivation of oregano may play an important role for Greek agriculture by providing high added value also on degraded slopping lands in the semi-arid zone of the country. This should be the subject of future land evaluation studies of oregano versus conventional cropping systems in specific soil-climatic environments so that cost/benefit projections can be produced. Extensive cultivation of oregano might be proved to be highly beneficial also for the environment, with respect to biodiversity conservation and minimizing soil erosion, land degradation and desertification processes in many degraded lands of the semi-arid zone in Greece, where oregano cultivation might be proved to be ideal.

\section{References}

Adam K, Sivropoulou A, Kokkini S, Lanaras T, Arsenakis M (1998). Antifungal activities of Origanum vulgare subsp. hirtum, Mentha spicata, Lavandula angustifolia and Salvia fruticosa essential oils against human pathogenic fungi.Journal of Agricultural and Food Chemistry 46:17391745.

Arnold N, Bellomaria B, Valentini G, Arnold HJ (1993). Comparative 
study of the essential oils from three species of Origanum growing wild in the eastern Mediterranean region. Journal of Essential Oil Resources 5:71-77.

Baricevic D, Bartol T (2002). The biological/pharmacological activity of the Origanum Genus. In: Kintzios SE(Ed). Oregano, the genera Origanum and Lippia. Taylor and Francis, London pp 177-213.

Baser KHC, Özek T, Tümen G, Sezik E (1993). Composition of the essential of Turkish Origanum species with commercial importance. Journal of Essential Oil Resources 5:619-623.

Baydar H, Sagdic O, Ozkan G, Karadogan T (2004). Antibacterial activity and composition of essential oils from Origanum, Thymbra and Satureja species with commercial importance in Turkey. Food Control 15:169-172.

Beltrán BJ, Franklin J, Syphard AD, Regan HM, Flint LE, Flint AL (2014). Effects of climate change and urban development on the distribution and conservation of vegetation in a Mediterranean-type ecosystem. International Journal of Geographical Information Science 28:15611589.

Bosabalidis AM, Exarchou F (1995). Effect of NAA and GA3 on leaves and glandular trichomes of Origanum $\times$ intercedens Rech. morphological and anatomical features. International Journal of Science 156:488-495.

Bosabalidis AM, Kokkini S (1996). Infraspecific variation of leaf anatomy in Origanum vulgare grown wild in Greece. Botanical Journal of Linnean Society 12:353-362.

Bouchra C, Achouri M, Hassani LMI, Hmamouchi M (2003). Chemical composition and antifungal activity of seven Moroccan Labiatae against Botrytiscinerea. Journal of Ethnopharmacology 89:165-169.

Bozin B, Dukic NM, Simin N, Anackov G (2006). Characterization of the volatile composition of essential oils of some Lamiaceae spices and the antimicrobial and antioxidant activities of the entire oils. Journal of Agricultural and Food Chemistry 54:1822-1828.

Chami N, Bennis S, Chami F, Aboussekhra A, Remmal A (2005). Study of anticandidal activity of carvacrol and eugenol in vitro and in vivo. Oral Microbiology and Immunology 20:106-111.

Cohen A, Putievsky E, Dafni A, Fleisher A (1980). Seed germination of wild spices from the "oregano" type. Hassadeh 60:1160-1162.

Conforti F, Ioele G, Statti GA, Marrelli M, Ragno G, Menichini F (2008). Antiproliferative activity against human tumor cell lines and toxicity test on Mediterranean dietary plants. Food and Chemical Toxicology 46:3325-3332.

Daferera DJ, Ziogas BN, Polissiou MG (2000). GC-MS analysis of essential oils from some Greek aromatic plants and their fungitoxicity on Penicillium digitatum. Journal of Agricultural and Food Chemistry 48:2576-2581.

Dhifi W, Jelali N, Mnif W, Litaiem M, Hamdi NJ (2013). Chemical composition of the essential oil of Mentha spicata $\mathrm{L}$. from Tunisia and its biological activities. Journal of Food Biochemistry 37(3):362-368.

Dordas C (2009). Foliar application of calcium and magnesium improves growth, yield, and essential oil yield of oregano (Origanum vulgare ssp. hirtum). Industrial Crops and Products 29:599-608.

Dordas C (2012). Aromatic and medicinal plants. Modern Education (Eds), Thessaloniki.
Dudai N (1988). Environmental factors affecting flowering, morphology and essential oil of Origanum syriacum var 'syriacum'. MSc Thesis, Hebrew University of Jerusalem.

Dudai N, Putievsky E, Palevitch D, Halevy AH (1989). Environmental factors affecting flower initiation and development in Majorana syriaca L. (Origanum syriacum var. syriacum). Israel Journal of Botany 38:229239.

Dudai N, Putievsky E, Ravid U, Palevitch D, Halevy AH (1992). Monoterpene content in Origanum syriacum as affected by environmental conditions and flowering. Physiologia Plantarum 84:453-459.

Friedman M (2014). Chemistry and multibeneficial bioactivities of carvacrol (4-isopropyl-2-methylphenol), a component of essential oils produced by aromatic plants and spices. Journal of Agricultural and Food Chemistry 62:7652-70.

Gergis V, Spiliotis V, Poulos C (1990). Antibacterial activity of essential oils from Greek Sideritis species. Pharmazie 45-70.

Goliaris A, Skroubis B (1992). New clones of Oregano. In: National Congress on Agricultural Research pp 201-214.

Goliaris A (1997). Origano cultivation in unproductive Greek land. Scientific Bulletin, Agricultural Resource Center of Northern Greece 4:79-86.

Goliaris A, Chatzopoulou P, Katsiotis S (2002). Production of new Greek Oregano clones and analysis of their essential oils. Journal of Herbs 10:29-35.

Harrison PA, Berry PM, Simpson G, HaslettJR, Blicharska M, Bucur M,... Turkelboom F (2014). Linkages between biodiversity attributes and ecosystem services: A systematic review. Ecosystem Services 9:191-203.

Katsiotis S, Chatzopoulou P (2010). Aromatic, medicinal and essential oil. Adelfhon KyriakidiEd, Thessaloniki.

Kintzios SE (2002). Oregano - The genera Origanum and Lippia. Agricultural University of Athens, Athens, Greece.

Kirimer N, Baser KH,Tumen G (1995). Carvacrol rich plants in Turkey. Journal ofChemistry of Natural Compounds 31:37-41.

Kokkini S, Vokou D (1989). Carvacrol-rich plants in Greece. Journal of Flavour andFragrance 4:1-7.

Kokkini S, Vokou D, Karousou R (1991). Morphological and chemical variation of Origanum vulgare L. in Greece. Botanica Chronica 10:337346.

Kokkini S, Karousou R, Vokou D (1994). Pattern of geographic variation of $O$. vulgare trichomes and essential oil content in Greece. Biochemical SystematicEvolution 22:517-528.

Kokkini S, Karousou R, Dardioti A, Krigas N, Lanaras T (1996). Autumn essential oils of Greek oregano (Origanum vulgare subsp. hirtum). Phytochemistry 44:883-886.

Koutsos T (2006). Aromatic and medicinal plants. Ziti, Thessaloniki, Greece.

Kulisic T, Radonic A, Katalinic V, Milos M (2004). Use of different methods for testing antioxidative activity of oregano essential oil. Journal of Food Chemistry 85:633-640.

Kuris A, Altman A, Putievsky E (1981). Root formation in oregano (Origanum vulgare L.) stem cuttings. Scientia Horticulture 14:151-156. 
552

Lawrence BM (1984). The botanical and chemical aspects of Oregano. Journal of Perfum Flavor 9:41-51.

Lewinsohn E, Ziv-Raz I, Dudai N, Tadmor Y, Lastochkin E, Larkov, ... Shoham Y (2000). Biosynthesis of estragole and methyl-eugenol in sweet basil (Ocimum basilicum L). Developmental and chemotypic association of allylphenol O-methyltransferase activities. Journal of Plant Science 160:27-35.

Makri O (2002). Cultivation of Oregano. In: Kintzios SE (Ed). Oregano, the genera Origanum and Lippia. Taylor and Francis, London and New Yorkpp 153-162.

Manohar V, Ingram C, Gray J, Talpur NA, Echard BW, Bagchi D, Preuss HG (2001). Antifungal activities of origanum oil against Candida albicans. Molecular and Cellular Biochemistry 228(1-2):111-117.

Marino M, Bersani C, ComiG(2001).Inpedance to study the antimicrobial activity of essential oils from Lamiaceae and Compositae. International Journal of Food Microbiology 67:187-195.

Marques PA, Bernardi FL, Frizzone JA (2012). Economic analysis for oregano under irrigation considering economic risk factors. Journal Horticultura Brasileira30:234-239.

Marzi V (1996). Agricultural practices for oregano. In: Padulosi A (Ed). Proceedings of the IPGRI International Workshop on Oregano 8-12 May 1996, CIHEAM, Valenzano, Bari, Italy.

Ozkan G, Sagdic O, Ozcan M (2003). Note: Inhibition of pathogenic bacteria by essential oils at different concentrations. Journal Food Science Technological International 9:85-88.

Panou-Filotheou H, Bosabalidis AM, Karataglis S (2001). Effects of copper toxicity on leaves of oregano (Origanum vulgare subsp. hirtum). Annals ofBotany (Lond.) 88:207-214.

Paster N, Juven BJ, Shaaya E, Menasherov M, Nitzan R, Weisslowicz H, Ravi U (1990). Inhibitory effect of oregano and thyme essential oils on moulds and food borne bacteria. Letters in Applied Microbiology 11:33-37.

Pellequer J,Jacob M, BuochbergMS, Allegrini J (1980). Therapeutic value of the cultivated Mountain Savory (Satureja montana L: Labiateae). Acta Horticulturae 96:35-39.

Putievsky E, Ravid U (1982). Variations in yield parameters in a wild population of Origanum vulgare L. In: Margaris N, Koedam A, Vokou D (Eds). Aromatic Plants: Basic and Applied Aspects. Martinous NijhoffPublishers, Te Hague, Boston, London pp 237-248.

Putievsky E (1983). Temperature and day-length influences on the growth and germination of sweet basil and oregano. Journal of Horticultural Science 58:583-587.
PutievskyE, Ravid U, Dudai N (1988). Phenological and seasonal influences on essential oil of a cultivated clone of Origanum vulgare L. Journal of Science Food Agriculture 43:225-228.

Ravid U, Putievsky E (1985). Carvacrol and thymol chemotypes of east Mediterranean wild Labiatae herbs (1986). In: Brunke E-J (Ed). Progress in Essential Oil Research, 16th International Symposium on Essential Oils, Holzminden-Neuhaus, Walter de Gruyter Publ, Berlin, Germanypp 163-167.

Remmal A, Bouchikhi T, Rhayour K, Ettayeby M, Tantaoui-Elaraki A (1993). Improved method for the determination of antimicrobial activity of essential oils in agar medium. Journal of Essential Oil Resources 5:179-184.

Sarac N, Ugur A, Duru ME, Varol O (2009). Antimicrobial activity, antioxidant activity and chemical composition of Origanum onites $\mathrm{L}$. and Origanum vulgare L. ssp. hirtum from Mugla (Turkey). Acta Horticulturae 826:397-404.

Seidemann J (2004). World Spice Plants. Springer 264, 266,336,365.

Sivropoulou A, Papanikolaou E, Nikolaou C, Kokkini S, Lanaras T, Arsenakis M (1996). Antimicrobial and Cytotoxic Activities of Origanum Essential Oils. Journal of Agricultural Food Chemistry 44:1202-1205.

Solomou AD, Martinos K, Skoufogianni E, Danalatos NG (2016). Medicinal and aromatic plants diversity in Greece and their future prospects: A review. Agricultural Science 4:9-21.

Solomou AD, Proutsos ND, Karetsos G, Tsagari K (2017). Effects of climate change on vegetation in Mediterranean forests: A review. International Journal of Environment, Agriculture and Biotechnology 240-247.

Tajkarimi MM, Ibrahim SA, Cliver DO (2010). Antimicrobial herb and spice compounds in food. Journal of Food Control 21:1199-1218.

Vokou D, Kokkini S, Bessiere JM (1993). Geographic variation of Greek oregano (Origanum vulgare ssp. hirtum) essential oils. Biochemistry Systematic Ecology 21:287-295.

Werker E, Putievsky E, Ravid U (1985a). The essential oils and gandular hairs in different chemotypes of Origanum vulgare L. Annals of Botany 55:793-801.

Werker E, Ravid U, Putievsky E (1985b). Structure of glandular hairs and identification of the main components of their secreted material in some species of the Labiatae. Israel Journal of Botany 34:31-45. 